\title{
Social Construction for the Twenty-first Century: A Co-Evolutionary Makeover
}

\section{Zoë Sofoulis}

\section{Introduction}

What do we do when good ideas reach their use-by date? The social constructionist thesis was valuable to me as a young 1970s feminist. It provided a platform from which to question, critique and change 'naturalised' views of gender and social position. Through engagement with feminist ideas, as well as structuralism, semiotics and discourse theory that emerged in the 1970s and 1980s, I became committed to notions of how categories of gender, race and class, and their associated social and economic functions, were not essential or natural, but were products of historical and material arrangements and power/knowledge formations. There was a libratory appeal to social constructionist arguments - such as those inspired by Peter L. Berger and Thomas Luckmann; Erving Goffman and Michel Foucault. The specifically gendered social constructionist arguments of Simone de Beauvoir were also significant, especially her asseveration that women were made not born. If things were socially constructed, they could be re-constructed: social change was possible. By changing people, we could change society; conversely, by changing society (which is understood as equivalent to language, or discourse), we could change the kind of people society constructs. For example, the Sapir-Whorf hypothesis (Whorf, Sapir) - that the worlds we perceived were bound by the limits of our language - was an inspiration for a feminist social experiment to construct a different social reality by resisting sexist language and inventing alternative forms.

Social constructionism was the weapon of choice against the traditional idea that, for those with gestational capacity, 'anatomy [or biology] is destiny'. Anti-biological-determinist arguments became entangled with political and legal anti-discrimination struggles that sought formal equality and choice for women and ethnic minorities, and remain relevant wherever repressive economic, political and religious agendas target populations because of their supposedly 'natural' or 'given' characteristics.

However, that a certain standpoint is or once was politically useful, necessary, or expedient does not guarantee its continued relevance as realities change, complexities emerge, and new concerns arise. Some limits to social construction became apparent in the early stages of the 'corporeal turn' of the 1980s, when the emphasis was on how the body was represented, and/or inscribed by society. 
Phenomena of 'embodiment' or experiences of the 'lived body' were overshadowed by theories of the body as a social construction (Crossley; Turner, 'Embodiment', 'Body'). These tensions were played out within and around the work of Judith Butler, whose Gender Trouble mobilised Foucaultian discourse analysis to unravel the sex/gender distinction (one version of the nature/culture dualism) into mutually defining co-constructions, whilst also re-animating the liberationist spirit of social construction through a performative theory of gender. Although Butler's Bodies that Matter responded to critiques of the earlier book's lack of attention to materiality and embodiment (Osbourne and Segal), many felt it was still too dependent on discourse and representation and did not sufficiently grapple with 'the in-itself of matter' (Kirby, Telling Flesh 107-08; see also Fiaccadori and Kirby, Judith Butler); more thoroughly physicalist accounts of bodies and their interactive performances were needed (and were developed, eg. by Diprose).

The insufficiently corporeal focus of social constructionist accounts of the body had left many feminists with 'a sense of disappointment in the failure really to engage with the materiality and flesh of the body', according to Keane and Rosengarten (202). Their discussion of 'the biology of sexed subjects' canvasses examples of drugs, organ transplants, intersex and transsexuals to highlight the complexities and ambiguities of interactions between nature, physiology, genes, culture, technologies and human and other species bodies as understood in the twenty-first century - complexities to which Haraway's 'Cyborg Manifesto' had alerted feminists a decade and a half ago, and which have been explored in a number of fields (see Sofoulis, 'Cyberquake') - including in conjunction with Butler's performative perspective (eg. Hird, Giffney and Hird). People might possess organs or body parts from other people or species, or in the form of technological implants and prostheses; sex can be changed through surgery and hormones. The formerly clear scientific distinctions between mind and brain or mind and body have become thoroughly blurred (see Damasio, and for feminist implications, Elizabeth Wilson). So too the genes versus environment dualism: epigenetics $^{l}$ is now recognised alongside genetic mutation as a source of variations in cells and bodies: genes may be switched on or off in response to changing external or internal environments. Moreover, new biomedical techniques can unpredictably alter the relations of self and other along with genotype and phenotype, as illustrated by the case of a young Sydney woman

\footnotetext{
${ }^{1}$ The term was coined in 1942 by geneticist C.H. Waddington to refer to vectors in developmental landscapes and complex systems (Waddington, Tools). During the 1990s, 'epigenetics' began referring to 'Nuclear inheritance which is not based on differences in DNA sequence' - contrasting with the prior 'dogma of the invariance of somatic cells' and models that only recognized mutations in DNA (genotype) as the source of changes in cells and bodies (phenotype) - but by 2001 it was understood that some environmentally-induced as well as developmental changes could produce changes in cells' nuclear material, some of which could be heritable (Lederberg). More recent research has identified the precise chemistry, and revealed that some so-called 'junk DNA' is involved in switching genes on and off.
} 
whose blood type and immune system inexplicably changed to that of her organ donor nine months after receiving a liver transplant (Alexander et al.).

'Social construction' was appealing in the 1960s and 1970s because society was considered mutable, whereas 'biological determinism' was anathema because biology was seen as an unchangeable, ahistorical given. But as social studies of sciences proceeded, it became increasingly apparent that the apparent fixity of biological categories (such as strictly dichotomous gender schemata) was largely an artefact of discourse that arose because scientific narratives were thoroughly pervaded by socially normative ideologies (as shown in Emily Martin's classic study; see also Oudshoorn, Hird). Moreover, for many scientists themselves, themes of mutability, indeterminacy, complexity, contingency, interactionism and context-dependency began to predominate over earlier certainties and predictabilities in knowledge of organisms and environments. As an anonymous reviewer of this paper noted, it is not only scientists of the $21^{\text {st }}$ century who understand biology and anatomy as mutable: nowadays it is an everyday experience of ordinary people who take anti-depressants, eat GM food, use reproductive technologies, etc'.

The current anthropogenic wave of extinctions and climatic disruptions dramatically demonstrate that 'nature' is no longer a 'given' but a 'taken'. Atmosphere scientist and biogeochemist Paul Crutzen has defined a new geological era, the 'Anthropocene', 2 in which human activities that alter carbon, nitrogen, phosphorus, sulphur, silicon and water cycles, and remove productive lands, forests and fisheries have accelerated to 'become a global geophysical force' (Crutzen) that is likely to remain effective 'over the next 50000 years' (Steffen, Cruzen and McNeill, 615). Public health statistics are pointing to the health and economic costs of phenomena such as extreme weather, water shortages, reduced biodiversity and lifeless oceans. All these effects result from complex multifactorical interactions that may be anthropogenic but now exceed any purely 'social' construction. These contemporary realities starkly remind us that our fates as humans are inextricably connected to the health of the world and the many non-humans on which we depend. With these drastic changes in knowledge and reality, is vehement opposition to 'biological determinism' still tenable? What is there left to fear in acknowledging that our social beings also

\footnotetext{
${ }^{2}$ Geologists had dubbed the last 10-12 (post-Ice Age) millennia as the 'Holocene' ('recent whole') period but Crutzen dates the start of the Anthropocene as coinciding with James Watt's design of the steam engine in late $18^{\text {th }}$ Century, from which point 'analyses of air trapped in polar ice showed the beginning of growing global concentrations of carbon dioxide and methane'. Steffen, Crutzen and McNeill suggest we are nearing the end of the second stage Anthropocene, the post-World War II 'Great Acceleration' of human activities with deleterious but unrecognised or disregarded impacts on the planet, and are on the brink of the third stage, where at least there is recognition of impacts, but no certainty that mitigation strategies will avert dangerous climatic tipping points-leading the authors reluctantly to raise the frightening and controversial prospect of deliberate atmospheric modification to deflect more sunlight away from Earth.
} 
express our genetic, hormonal and neuro-physical selves, ${ }^{3}$ and our epigenetic responses to contingencies in our changing social and material environments - however degraded and precarious?

Because my primary intellectual interests have centred around humans, bodies, technologies and (ir)rationality, and have been underpinned by environmental concerns, I have been increasingly drawn to constructionist frameworks that are not founded on a dichotomy between the social and the material or biological worlds. Three decades ago, Gregory Bateson helped me take first steps on a path that was later continued in readings of Donna Haraway, Don Ihde, Bruno Latour, and other actor-network and sociotechnical theorists through whom I have come to appreciate perspectives that are unafraid of acknowledging the active roles bodies and non-human entities play in our socialisation as humans (see collections by Bijker and Law, Cockburn and Fürst-Dilic, Gill and Grint, Law and Hassard, Ihde and Selinger, Latour and Weibel). According to actor network theory (ANT), human and non-human elements of systems are entities that are 'bound together in networks [and] are at the same time, constituted and shaped in those networks' (Bijker and Law 13); properties, capacities and powers to act are distributed across human and non-human agents. Terms like 'material-semiotic', 'actor-network', 'sociotechnical', 'bio-social' , 'co-constructionist' , 'interactionist' and 'co-evolutionary' signal post-dichotomous ways of viewing, investigating, describing and theorising the interplays of social, technical, biological and environmental factors in shaping the fates of individuals, genders and populations. Perspectives informed by systems thinking, complexity theory and notions of co-evolution (or co-construction) have emerged or been adopted across a range of fields that increasingly evade the old modern disciplinary divide between social and natural sciences lambasted by Latour in We Have Never Been Modern. In human geography, which has traditionally payed greater attention to heterogenous and spatialised assemblages than the more purely social sciences, some recent 'non-essentialist materialisms' (Anderson and Braun xiv ${ }^{4}$ ) include Nigel Thrift's 'non-representationalist' thought, and Sarah Whatmore's 'hybrid' or 'more than human' geographies.

Many readers of $A H R$ will no doubt be familiar with some of these transdisciplinary paradigm shifts (including in the social sciences; see Law). However, traditional disciplinary commitments to human-centred modes of inquiry make some in the humanities and social sciences reluctant to entertain these 'more-than-human' perspectives, while younger scholars familiar with ANT and related ideas may not appreciate their kinship with earlier forms of

\footnotetext{
3 Including of course our 'natural' disposition to be social!

4 Anderson and Braun introduce their recent collection of human geography essays on the theme of environment with an illuminating review of successive materialisms influential within the field, citing Gilles Deleuze, Donna Haraway, Alfred Whitehead, Michael Serres and Bruno Latour as contemporary inspirations (xiv). See also Whatmore, 'Materialist Returns'.
} 
social construction. This paper is primarily aimed at helping both kinds of readers find bridges between human and more-than-human versions of social construction.

Viewed in the light of contemporary knowledges and material realities, social construction is looking rather outdated. To borrow the vocabulary I learned from Meredith Jones' dissections of makeover culture (Skintight, 'Mutton'), social construction has come to resemble a 1970s celebrity who is not 'ageing well': she's become a repetitive and unconvincing grumpy old woman who arguably needs a conceptual makeover to stay attractive and relevant. Can she once again inspire re-constructions of people, languages, practices and worlds? It is possible for her to enjoy what Jones calls a 'stretched middle age' and be re-capacitated as an ally for twenty-first century movements and policies supporting sustainability and diversity in both nature and society? I am not entirely sure.

One persuasive thinker for whom conventional forms of social constructivism seem irretrievably passé is the physicist and feminist theorist Karen Barad, who argues that both sides in 'the hackneyed debate between scientific realism and social constructivism' shared commitments to representationalism which assumed rather than questioned the ontological distinguishability of signs from their represented entities. The only question that debate left open was whether the signs represented real world things (e.g. objects in 'Nature') or were social products (805-06). Barad pursues an alternative 'onto-epistemo-logy' ('The Study of Practices of Knowing in Being' 829) that accords far more active, formative and (pace Butler) performative roles to matter, corporeality and the non-human. Drawing explicitly on themes of indeterminancy and interactivity from physicist Neils Bohr's epistemology, Barad pictures an ontological equivalence between real world things (including apparatus), the traces of events and phenomena that could become signs and knowledge (such as scientific data and charts), and those knowers who would seek to observe and understand these entities and traces. These co-arise and co-generate each other in 'intra-actions', defined as 'causally constraining nondeterministic enactments through which matter-in-the-process-of-becoming is sedimented out and enfolded in further materializations' (823). Intra-actions produce phenomena and establish the very possibility of objects and prospective knowers of objects coming into being and relating to each other - a precondition for any subsequent representational relationship. ${ }^{5}$ We might imagine Barad dismissing even an extreme makeover of social construction as a merely cosmetic or 'phenotypic' change. Why bother,

\footnotetext{
5 Thus, to caricature both authors, whereas Latour creates a 'more than human' polity by turning non-humans into quasi-human political subjects, with representatives, rights and political claims upon us, Barad's 'post-human performativity' pictures interactions (and 'intra-actions') amongst humans and non-humans as akin to indeterminate quantum events.
} 
when her brave new 'onto-epistemo-logy' performs radical mutations and hybridisations to generate an entirely different kind of creature?

Nevertheless, driven by a mix of nostalgic loyalty towards the old trouper, a spirit of experimentation, and an ethic of 're-use', I am proposing here to leave aside Barad's intriguing approach, and attempt a renovation of the social constructionist framework. The first stage of the procedure has already begun: excavating and highlighting the interesting and complicated 'stuff' that abounds amid the ruins of old modern dualisms. The second stage is a Latourian opening up of 'the social' to admit a greater variety of socialised and socialising agents. The last procedure is reconstructive work on the idea of 'construction' to make it flexible enough to fit into a co-evolutionary model. Finally, the 'reveal': the re-vamped model is tried out with reference to issues of urban water cultures, technologies and systems, highlighting the socially shaping effects of urban infrastructures.

\section{Procedure 1. Complex connections}

Latour's polemic against the old modern project (We have never...) taught us to be suspicious of neat dichotomies of modern disciplines and concepts that separate human from non-human, facts from values, the material from the semiotic, and nature from culture. Those efforts at 'purification' overlook the messy hybridities, human/non-human entanglements and 'in between' states of 'naturecultures' where 'real stuff' happens. Surely I am not the only humanities academic to have experienced a queasy dissociation about teaching undergraduates how to critique Enlightenment thought and the old modernist dichotomies, even as these were collapsing in practically all branches of science, and were exceeded in everyday life by the strange experiences, metamorphosed bodies and new knowledges enabled by technoscience. Such phenomena enjoin us to acknowledge complexity and interconnectivity in what counts as nature, human, social or self; they challenge us to worry less about defending disciplinary boundaries, and do more to cultivate points of connection with other knowledges and frameworks around matters of common concern, the 'things' that matter to a larger public and that co-constitute us as members of a more-than-human polity (see Latour and Weibel).

\section{Procedure 2: Opening up the 'social'}

Humans for a few millions of years now have extended their social relations to other actants with which, with whom, they have swapped many properties, and with which, with whom, they form a collective. There is no sense in which the notion of a human can be disentangled from the nonhumans into whose fate it has woven more and more intimately over the ages. (Latour, 'Pramatogonies' 793) 
Latour's imagined 'parliament of things', where even non-human actants have rights and forms of representation, is predicated upon a refusal of the old modern disciplinary divide between human and physical and natural sciences, and a radical redefinition of 'society' or 'the social' to include the multifarious non-humans we live with and which sustain us. Or perhaps assault us. For as Stephen Muecke reminds us in his meditations on house dust mites, allergies and treatments, researchers ought not be too hasty or short-sighted when drawing a boundary around the list of actants relevant to a problem: 'let's not foreclose too soon on possible actors or causes in the assemblages that make up matters of concern'. In this perspective, the process of social construction includes formative interactions with the non-human entities - like house dust mitesthat are also part of our everyday social lives.

It is worth remembering that Latour and Woolgar produced their early version of actor-network theory out of social constructionist research into the social and discursive construction of scientific facts. As well as revealing how facts and artefacts are so constructed, their studies also disclosed how matter, machines, and organisms may resist conforming to humans' semiotic frames, and how these non-human agents also shape and organise human groups, knowledge, and realities (See Latour and Woolgar; Latour, 'Pragmatogonies'; Haraway, Simians; Modest; Dugdale; Law).

Latour has routinely critiqued conventional sociology for having neglected the role played by non-human entities in constructing, stabilising and supporting social systems (Latour 'Pragmatogonies'), and for holding too fixed a view of 'society' as a fully-formed structure or set of institutions and forces, a macro-sociological agent that constructs humans and shared realities. His actor-network theory seeks to understand 'society in the making': the processes of 'heterogeneous engineering' through which facts and artefacts, personages, social categories, and societies are constructed from the ground up through practices and interactions amongst a variety of types and scales of actors, not all of them human or even animate. Mike Michael characterises Latour's approach as a microsociology that avoids 'such macro terms as institutions, the state, class, race, patriarchy' and is more interested in 'how these complexes attain coherence, consistency and uniformity across time and space' (Michael 31). He contrasts Latour with Haraway, who 'is not averse to drawing upon the traditional terms of macrosociology - ideology, multinationals, sexism, racism and so on' and who sees these structures 'as conditions and products of networks', whose effects are indirect, mediated, and difficult to empirically demonstrate. However, this macro/micro binary cannot be maintained, especially as Latour's more recent textbook on ANT relaxes this polemic and concedes there are indeed social phenomena, categories and artefacts so firmly entrenched and 'stabilised' that the microsociological study of ' $[\mathrm{X}]$ in the making' is inappropriate (Reassembling Ch. 3). The key point is that networks are heterogeneous and include entities 
and sub-networks of different scales and types, and members of micro-networks inevitably have connections with 'meso-' as well as 'macro-' level formations.

With non-humans included in the social domain, and society understood as a heterogeneous assemblage of humans, plants, animals, technologies, infrastructures, natural entities and contingent events, the idea of 'social construction' can be unfolded to encompass a more complex set of processes, and a more diverse set of actors and practices, than sociologists and cultural researchers conventionally consider. For example, whereas social theories of gender conventionally centre on human agents (language, kinship structures, norms of masculinity and femininity), a sociotechnical approach would examine how specific variants of gender are constructed, performed, and exceeded in interactions with non-humans: toys, clothes, adornments, grooming technologies, domestic spaces, plants and animals; machines and workspaces, as well as surgery, hormones or drugs. One difference between conventional and 'more than human' versions of social construction is that while the latter seek to understand 'gender in the making', they do not presume that all interactions with non-humans are subsumed by or reproduce the symbolic and social orders of gender: interactions with non-humans include contingent 'intra-actions' (see Barad) and have specific material, corporeal, pre-representational or non-representational effects.

Expanding the social to include non-humans means that to understand how I have been socially constructed, in addition to considering interactions with social institutions like family, school, social norms and laws. I would also examine the roles played by the foods, drinks and other substances that I (or my mother and grandmothers) have eaten or overeaten (i.e. epigenetic factors), the animals I have encountered as pets or as meat on my plate, as well as the material objects with which I have interacted, from childhood toys to car and laptop. My social identity as a worker who can show up on time in a presentable state is enabled by interactions with numerous fittings, appliances and products for timekeeping, personal hygiene, and laundering, as well as the infrastructures of water, electricity and transport, all of which could be understood as 'progenitors' or 'co-agents' of my acculturation into a shared way of life.

\section{Procedure 3: Reconstructing 'construction'}

'Construction' implies a process of bringing together, and by association with building may connote intentional processes of design, planning, coordinating, assembling and finishing. A crucial move in sociotechnical or actor-network thinking is to de-couple the notions of action and agency from the notions of intentions or intended effects. For example, a car that won't start, or a doorsill we stub our toe on, do not have malevolent intentions but they do have effects. On the other hand, the ways artefacts are designed and deployed may have human intentions 'baked into' them, and have moral effects in that they carry certain injunctions to action and script roles for their users (Latour, 'Missing 
Masses'). 'Shaping' may be a better word than 'construction' to suggest a more contingent and partly random process with a number of agents involved, not necessarily fully coordinated by some maestro conductor. The term 'co-construction' is meant to suggest a process in which these mutually formative - though not necessarily planned - interactions between a number of heterogeneous agents have effects upon these agents and upon the network(s) in which they participate.

From understanding 'construction' as a form of 'co-construction', we can begin to contemplate the dynamic processes of 'co-evolution', where actors and 'products' (or entities) in networks continually interact with and mutually shape each other, meaning that each 'construction' is a dynamic co-construction that changes over time or in successive iterations, along with other elements in the network that together 'co-evolve'. ${ }^{6}$ Elizabeth Shove has outlined one version of a basic sociotechnical co-evolutionary system in the form of a triangle whose three poles are the habits and expectations of users (or 'user cultures'), the technologies and objects they use, and the collective conventions and arrangements associated with large-scale social structures and technocratic infrastructures (Shove, Comfort 48; see also Sofoulis and Williams 54). Two-way arrows between each pole indicate co-constitutive interactions between user cultures, technologies, and systems, each of which adaptively changes and evolves in response to interactions with the others.

A minor example of co-evolutionary change is furnished by low-flow shower heads in Sydney. Householder expectations about the convenience and comfort of showering have been shaped by the existence of urban water infrastructures, as well as technological devices like showers and hot water systems. When the water utility first promoted water-efficient shower heads, some users were disappointed that the new showers did not deliver the expected water flow and sensations of wetness, or were not stylish enough to suit their bathrooms. A co-evolutionary change arguably occurred when the water utility expanded its range of rebate-attracting shower heads to include 'wetter' models and prestige designs. The 'co-evolution' aspect here is not locatable simply in the technological innovation, but the shift in user-utility relationship it mediated: instead of persisting with a typical top-down and engineering-centred approach to water efficiency, the utility actually listened and responded to users' expectations about sensations and aesthetics.

\footnotetext{
${ }^{6}$ Co-evolution is a term used in evolutionary biology, mainly to describe how changes in one organism may prompt or be accompanied by changes in another; for example how flower shapes co-evolve with specific features of particular insects and birds involved in their pollination or seeding. Describing the dynamics of change within sociotechnical systems as 'co-evolutionary' might be considered metaphorical as no biological or genetic change is immediately involved. However, the lesson of the early Anthropocene is that sociotechnical systems are not ultimately separable from planetary life support systems, and result in new genetic and epigenetic pressures on organisms to either change and adapt, or suffer extinction, the death of future evolutionary potential.
} 


\section{Co-evolution and urban water}

In its 1970s version, social construction helped us understand how persons were products of social structures. Its makeover has turned it into a model of sociotechnical (or socio-natural-technical) co-construction, and of change via co-evolution. This enhances its relevance for addressing current issues, including how we are shaped by technologies and infrastructures as well as our fellow living entities, and how we, our technologies and infrastructures need to co-evolve into different configurations in order to mitigate climate change and other forms of environmental instability.

So now I could describe myself as a sociotechnically constructed water consumer who has been shaped by interactions with technologies like the tap and the drain. These non-human actants, along with habits and practices encouraged by parental injunctions, school and workplace rules, popular media, have helped 'co-construct' me as a citizen and water consumer. These ordinary plumbing fittings are part of a sociotechnical assemblage that produced me as a 'clean and proper' citizen who can knowledgeably use water services to accomplish this self-presentation. Municipal water and sewerage infrastructures have 'baked into' them certain kinds of intentions (and 'non-intentions') about heroic engineering, civilization, public health and municipal order (Sofoulis). They enabled technologies like flushing toilets, hot water systems and automatic washing machines to flourish. My interactions with them have built up my expectations about levels of comfort and convenience with which I can achieve socially normative standards of cleanliness and freshness (Shove Comfort; Medd and Shove). These inherited technologies and infrastructures were designed with abundance not sustainability in mind, and so possess 'saver-unfriendly' features that prevent people like me from routinely using less water (Allon and Sofoulis).

There is growing recognition of the urgent need for changes in our ways of life, including how we use water, what kinds we will use, and what new systems of urban water service provision might evolve. However, unlike postmodern science, urban water management is still conducted in old modern disciplinary terms. Water behaviour, attitudes, values and socio-economic status are all categorised as 'social' or 'human', while water management and supply and associated devices are categorised as factual, technical, natural-'non-human'. With such stringent 'purifications' dividing the humans from the non-humans, no wonder water industry people refer to the problem of how to change human behaviour as 'the hard stuff'. Instead of studying water practices, the industry has exhaustively investigated individual attitudes and population demographics via methods blind to the messy in-between zones where humans, social norms, water, technologies and infrastructures all interact, and where new practices and water cultures may be found 'in the making'. By contrast, in a recent project 
on urban water demand management, ${ }^{7}$ we argued for a 'meso-' level approach to changing water culture norms and diffusing alternative technologies and practices, by engaging people in peer-based and practical learning about conservation via formal and informal social organisations based outside the home (eg. in the street or neighbourhood, through sports clubs, faith-based organisations, community groups, etc.).

In their study of contemporary household projects, Shove and her collaborators (Design) elaborate on the practice-centred theory at the heart of the co-evolutionary approach. Theories of practice 'require an analysis that goes beyond the realm of symbolic communication, and beyond the actions of seemingly autonomous individuals' (11). In the domestic context, the practicalities of doing things like making a meal 'generally involve the active orchestration of an array of material artefacts' that are 'brought together in a spatially and temporally structured arrangement' (142). The co-evolutionary model suggests that the most effective pathways to new water consumption cultures will involve the 'active orchestration' of an array that includes material artefacts (eg. water-collection or saving technologies) and new practices, as well as people, organisations, and large-scale systems.

The co-evolutionary model implies that strategies aimed at changing just one actor or set of (inter-) actions in a co-evolutionary network might not succeed, or they could precipitate unintended or unwelcome changes in other actants and interactions in the network. For example, in response to tight restrictions on outdoor water uses in Sydney, many householders started diverting washing machine and bath water onto their gardens. Additionally, disgust at using drinking water to flush toilets helped prompt a shift in etiquette and standards of hygiene and privacy, and people flushed their toilets less frequently. A couple of years on, the water utility was advertising for specialist engineers to cope with the increased odour and accelerated corrosion of sewerage pipes that were carrying significantly lower volumes of water and more concentrated wastes. This situation had the potential to make visible the normally unmentionable facts that the sewerage system itself was not designed for frugality, that it has its own built-in 'demands' for water (normally disguised when utilities define users as wholly responsible for demand), and that it becomes fragile when those otherwise unacknowledged systemic demands are not met. It illustrates how through their well-intentioned and unpredicted conservation practices, users could potentially damage infrastructures.

\footnotetext{
7 This project Demand Management through Cultural Innovation: User Models was undertaken as a partnership between the Centre for Cultural Research, University of Western Sydney and Sydney Water Corporation in 2005-07, and the support of these two institutions is gratefully acknowledged. The research team comprised the author with Dr Carolyn Williams, Marnie Campbell and Dr Penny Rossiter, with research assistance from Justine Humphry and Jude Twaddell and management support from Dr Peter Wejbora.
} 
A co-evolutionary approach suggests alternatives to current urban water demand management planning, where existing historical, technical and cultural norms of water use are typically taken as a baseline, and much effort is focussed on meeting these demands by delegating responsibility for water saving to more efficient technologies (eg. low-flow showerheads, dual flush toilets). These efficiency solutions achieve some savings in resource use without requiring changes in either consumption norms or large-scale systems and infrastructures of consumption (van Vliet, Chappells and Shove, 16). They are therefore only 'weakly' co-evolutionary.

A more deliberate co-evolutionary approach could accelerate change for sustainability by working directly on renegotiating consumption norms and requirements while new technologies and infrastructures co-evolve to support them. A 'strong' co-evolutionary approach would help communities to coordinate interactions and alignments amongst key actors in heterogeneous networks that support water-saving as well as co-provision (Chappells). For example, well-designed waterless toilets exist but are not widely adopted in Australia, largely due to lack of intermediary businesses equivalent to those available for supporting backyard pools (Fam). No matter how good the technology, it cannot spread far beyond hard-core enthusiasts without appropriate infrastructures and user support services. In a stronger co-evolutionary approach, ordinary water users can become more than mere conscience-stricken vectors by which houses acquire water-saving devices: they can become co-responsible for water saving and be active and adaptive agents in changing water cultures and expectations about water services. In concert with appropriate technologies (like rainwater tanks or greywater recycling devices), and their own resourcefulness and inventiveness, water consumers might co-evolve new identities as water collectors, recyclers and savers (Sofoulis and Williams, 55). One effect of such actions, especially in concert with adoption of new water technologies and techniques (such as rainwater collection and greywater recycling), is to alter the existing user-provider relationship, as users change from dependent 'customers' to active 'co-providers' and 'co-managers' of water - changes which Medd and Chappells (47-8) observe are often resisted by water authorities. For like its 1970s predecessor, this revamped constructionism is animated by a libratory spirit that encourages critical questioning of authorities (both technical and social), along with encouraging invention, experiment and reconstruction to co-create a better (or less worse) world.

\section{Conclusion}

The 1970s version of social construction was inspirational for its de-naturalising of gendered representations and identities based on ideologies of 'anatomy is destiny'. In the updated social construction proposed here, anatomy still isn't destiny - though the body is more agentic, mutable and adaptive (even more 
so for Barad). 'Society' is a heterogeneous collectivity where humans socialise and are socialised by natural elements, technologies and infrastructures that establish certain basic habits and expectations of levels of convenience and resources available for accomplishing diverse tasks. 'Construction' is a 'co-construction', a multilateral configuration involving distributed agency and co-evolutionary interactions that help stabilise and maintain - or alternatively, potentially destabilise, mutate or extinguish — networks and their heterogeneous actors.

Whereas the earlier version of social construction called attention to the structuring forces of social institutions as products of history not nature, this twenty-first century sociotechnical update draws our attention to the inconspicuous and backgrounded technologies and infrastructures that support daily social and bodily life. Making those infrastructures and our habitual relations to them more visible and accountable is an important step towards co-evolving more sustainable infrastructures, cultures and identities. The new systems, infrastructures and technologies that emerge will demand and facilitate new kinds of practices, different sets of relations (e.g. among and between humans and infrastructures) and in turn co-construct different kinds of people.

Dr Zoë Sofoulis (a.k.a. Zoë Sofia) is an independent scholar and Adjunct Fellow at the Centre for Cultural Research at the University of Western Sydney, where she was previously a senior lecturer in Humanities. With background interests in the intersections of culture, technology, gender and irrationality, and recent projects in applied humanities partnerships, her current preoccupation is with how our cultural norms and identities are formed in relations with urban and domestic infrastructures, and processes of changing these relationships.

\section{Acknowledgements}

I gratefully acknowledge the ARC Cultural Research Network for its support of activities in the background to this publication. The CRN's 'naturecultures' group, especially fellow panel presenters Gay Hawkins, Stephen Muecke and Emily Potter, but also Kay Anderson, have provided a highly stimulating, generous and encouraging environment for exploring new materialisms beyond cultural studies. Thanks to Gay and Emily for creating an octet out of two quartets, for exchange and workshopping of papers with the Melbourne University postgraduates Michael Dieter, Bjorn Nansen, Janine Randerson and Nathaniel Tkacz, following our meeting at the annual Cultural Studies Association of Australasia conference in Adelaide, December, 2007, and eventually leading to this publication. I'm also grateful to Gay Hawkins and Kay Anderson for arranging the 'More than Human Modes of Inquiry' workshop with Sarah 
Whatmore in November 2008, which introduced me to new directions that informed revisions of this paper. The water examples were informed by research conducted through the Centre for Cultural Research at the University of Western Sydney (see note 7) and I would especially like to thank Carolyn Williams for her contributions to ideas about urban water demand and water-saving networks. Finally, thanks to the editors and anonymous reviewers for kind comments and helpful suggestions.

\section{Works Cited}

Alexander, Stephen I., Neil Smith, Min Hu, Deborah Verran, Albert Shun, Stuart Dorney, Arabella Smith, Boyd Webster, Peter John Shaw, Ahti Lammi, and Michael O. Stormon 'Chimerism and Tolerance in a Recipient of a Deceased-Donor Liver Transplant.' New England Journal of Medicine 358 (Jan. 2008): 369-374.

Allon, Fiona and Zoë Sofoulis. 'Everyday Water: Cultures in Transition.' Australian Geographer 37.1 (2006): 151-79.

Anderson, Kay and Bruce Braun. 'Introduction.' Environment: Critical Essays in Human Geography. Ed. Kay Anderson and Bruce P. Braun. Aldershot: Ashgate, 2008.

Barad, Karen. 'Getting Real: Technoscientific Practices and the Materialization of Reality.' differences: A Journal of Feminist Cultural Studies 10.2 (1998): 87-126.

- 'Posthumanist Performativity: Toward an Understanding of How Matter Comes to Matter.' Signs 28.3 (2003): 801-31.

Berger, Peter and Thomas Luckmann. The Social Construction of Reality: A Treatise in the Sociology of Knowledge. Garden City NY: Doubleday, 1966.

Bijker, Weibe E. and John Law, eds. Shaping Technology/Building Society. Cambridge, Mass.: MIT Press, 1992.

Butler, Judith. Gender Trouble: Feminism and the Subversion of Identity. London: Routledge, 1990.

-. Bodies that Matter: On the Discursive Limits of 'Sex.' London: Routledge, 1993.

Chappells, Heather. 'Institutions, infrastructures and the construction of water demand.' Presentation for Traces of Water Project Workshop 3 (10 Nov 2005). http://www.lec.lancs.ac.uk/cswm/dwcworkshop3.php . Accessed 26 Aug 2008. 
Cockburn, Cynthia and Ruza Fürst Dilic, Eds. Bringing Technology Home: Gender and Technology in a Changing Europe. Birmingham: Open University Press, 1994.

Crossley, Nick. 'Body-Subject/Body-Power: Agency, Inscription and Control in Foucault and Merleau-Ponty.' Body and Society 2.2 (1996): 99-116.

Crutzen, Paul J. 'Geology of mankind' Nature 415.6867 (3 Jan 2002): 23. http://www.nature.com/doifinder/10.1038/415023a . Accessed 18 February 2009.

Damasio, Antonio R. 'How the Brain Creates the Mind.' Scientific American 281.6 (Dec 1999): 112-117. http://search.ebscohost.com/login.aspx ? direct $=$ true $\& \mathrm{db}=\mathrm{a} 9 \mathrm{~h} \& \mathrm{AN}=2464646 \&$ site $=$ ehost-live Accessed UWS Library 12 Feb 2008.

De Beauvoir, Simone. The Second Sex. Trans. H. M. Parshley. Harmondsworth: Penguin.

Diprose, Rosalind. 'Performing Body-Identity.' Writings on Dance, 11/12 (1994): 6-15.

-. Corporeal Generosity: On Giving with Nietzsche, Merleau-Ponty and Levinas. Albany: State University of New York Press, 2002.

Dugdale, Anni. 'Materiality: Juggling Sameness and Difference.' Actor Network Theory and After. Eds John Law and John Hassard. Oxford: Blackwell, 1999. 113-135.

Fam, Dena. 'Design and Cultural Acceptability of Waterless Toilets.' Paper for In the Pipeline - New Directions in Cultural Research on Water, University of Western Sydney, Parramatta Campus, NSW, July 2007. Abstract at http://www.uq.edu.au/crn/pipeline/abstracts/fam.html .

Fiaccadori, Elisa. "The Question of "Nature": What has Social Constructionism to offer Feminist Theory?' Goldsmiths, University of London, Sociology Working Papers, 2006.

http://www.goldsmiths.ac.uk/sociology/papers/fiaccadori_booklet.pdf . Accessed 16 Feb 2009.

Foucault, Michel. The History of Sexuality Vol. 1: An Introduction. New York: Vintage, 1980.

Giffney, Noreen and Myra J. Hird, Editors. Queering the Non/Human. Aldershot: Ashgate, 2008.

Gill, Rosalind and Keith Grint. The Gender-Technology Relation: Contemporary Theory and Research, London: Taylor and Francis, 1995.

Goffmann, Erving. The Presentation of Self in Everyday Life. New York: Doubleday/ Anchor Books, 1959. 
Haraway, Donna. 'A Manifesto for Cyborgs: Science, Technology and Socialist feminism in the 1980s.' Socialist Review 80 (Mar-Apr 1985): 65-107. (Also in Simians)

-. Simians, Cyborgs, and Women: The Reinvention of Nature. New York: Routledge, 1991.

—.Modest_Witness@Second_Millenium FemaleMan ${ }^{\odot}{ }_{\text {_Meets_OncoMouse }}{ }^{\mathrm{TM}}$. New York: Routledge, 1997.

Hawkins, Gay. 'Down the Drain: Shit and the Politics of Disturbance.' UTS Review 7.2 (2001): 32-42.

-. The Ethics of Waste: How We Relate to Rubbish. Lanham, MD: Rowman and Littlefield, 2006.

Hird, Myra. 'For a Sociology of Transsexualism.' Sociology 36 (2002): 577-595.

Ihde, D. Technology and the Lifeworld: From Garden to Earth. Bloomington: Indiana UP, 1990.

—. Philosophy of Technology. New York: Paragon Press, 1993.

Idhe, Don, and Evan Selinger, eds. Chasing Technoscience: Matrix for Materiality. Bloomington: Indiana University Press, 2003.

Jones, Meredith. 'Mutton Cut Up as Lamb: Mothers, Daughters and Cosmetic Surgery', Continuum: Journal of Media and Cultural Studies 18.4 (2004): 525-39.

-. Skintight: An Anatomy of Cosmetic Surgery. Oxford: Berg, 2008.

Keane, Helen and Marsha Rosengarten. 'On the Biology of Sexed Subjects.' Australian Feminist Studies 17.39 (2002): 261-77.

Kirby, Vicki. Telling Flesh: The Substance of the Corporeal. London: Routledge, 1997.

—. Judith Butler: Live Theory. London: Continuum, 2006.

Latour, Bruno, We Have Never Been Modern. Trans. Catherine Porter. Cambridge, Mass.: Harvard UP, 1993 [1991].

- . 'Where Are the Missing Masses? The Sociology of a Few Mundane Artifacts' Shaping Technology/Building Society. Eds Weibe E. Bijker and John Law. Cambridge, Mass.: MIT Press, 1992. 225-64.

—. 'Pragmatogonies.' American Behavioural Scientist 37.6 (1994): 791-808.

-. Reassembling the Social: An Introduction to Actor-Network Theory. Oxford: Oxford UP, 2005.

Latour, Bruno, and Peter Weibel, Eds. Making Things Public: Atmospheres of Democracy. Cambridge, Mass.: MIT Press, 2005. 
Latour, Bruno, and Steve Woolgar Laboratory Life: The Social Construction of Scientific Facts. Beverly Hills: Sage Publications, 1979.

Law, John. After Method: Mess in Social Science Research. London: Routledge, 2004.

Law, John and John Hassard, eds. Actor Network Theory and After, Oxford: Blackwell, 1999.

Lederberg, Joshua. 'The Meaning of Epigenetics.' The Scientist 15.18 (Sept 17, 2001): 6. Accessed Academic OneFile, UWS, 18 Feb. 2009.

Martin, Emily. 'The Egg and the Sperm: How science has constructed a romance based on stereotypical male-female roles.' Signs 16.3, Spring 1991: 485-501.

Medd, Will and Heather Chappells. 'From Big Solutions to Small Practices: Bringing Back the Active Consumer.' Social Alternatives 27.3 (2008): 44-49.

Medd, Will and Elizabeth Shove. The Sociology of Water Use (07/CU/02/2). London: UK Water Industry Research Ltd (UKWIR), 2006. http://www.ukwir.org/ukwirlibrary/91460 Accessed 19 Feb 2009.

Michael, Mike (2000) Reconnecting Culture, Technology and Nature. London: Routledge.

Muecke, Stephen. 'Evolving Nature of Cultural Studies.' Higher Education Supplement, The Australian, 6 February 2008. $<\mathrm{http}: / /$ www.theaustralian.news.com.au/story/0,25197,23164967-25192,00.html> Accessed 19 Feb 2009.

Osbourne, Peter and Lynne Segal. 'Extracts from Gender as Performance: An Interview with Judith Butler.' [Original interview in Radical Philosophy 67, Summer 1994.]. http://www.theory.org.uk/but-int1.htm . Accessed 18 Feb 2008.

Oudshoorn, Nelly. Beyond the Natural Body: An Archeology of Sex Hormones. London: Routledge, 1994.

Sapir, Edward. Selected Writings of Edward Sapir in Language, Culture, and Personality. Ed. David G. Mandelbaum. Berkeley CA: University of California Press, 1983.

Sapir, Edward. Language: An Introduction to the Study of Speech. New York/Maryland: Courier Dover Publications, 2004 [1921].

Shove, E. Comfort, Cleanliness and Convenience: The Social Organization of Normality. Oxford: Berg, 2003.

Shove, Elizabeth, Matthew Watson, Martin Hand and Jack Ingram. The Design of Everyday Life. Oxford: Berg, 2007. 
Sofoulis, Zoë. 'Cyberquake: Haraway's Manifesto' Prefiguring Cyberculture: An Intellectual History. Ed. Darren Tofts, Annemarie Jonson and Alessio Cavallaro, Sydney/ Cambridge/London: Power Publications/ MIT Press, 2003. 84-103.

- 'Big Water, Everyday Water: A Sociotechnical Perspective.' Continuum: Journal of Media and Culture 19.4 (2005): 445-63.

Sofoulis, Zoë, and Carolyn Williams. 'From Pushing Atoms to Growing Networks: Cultural Innovation and Co-Evolution in Urban Water Conservation' Social Alternatives 27.3 (2008): 50-7.

Steffen, Will, Paul J. Crutzen and John R. McNeill.'The Anthropocene: Are Humans Now Overwhelming the Great Forces of Nature?' AMBIO: A Journal of the Human Environment 36.8, 2007: 614-21. Accessed via BioOne, 18 Feb 2009.

Thrift, Nigel. 'Afterwords' Environment and Planning D: Society and Space. 'After Networks' Special Issue. Ed. Kevin Hetherington and John Law. 18:2 (2000): 213-55.

Turner, Bryan S. 'The Embodiment of Social Theory.' Introduction to The Body and Society, $2^{\text {nd }}$ ed. Ed. Bryan S. Turner. London; Sage, 1996. 1-35.

—. 'Body.' Theory, Culture \& Society 23.2-3 (2006): 223-36.

Van Vliet, Bas, Heather Chappells and Elizabeth Shove. Infrastructures of Consumption. London: Earthscan, 2005.

Whorf, Benjamin. Language, Thought, and Reality: Selected Writings of Benjamin Lee Whorf. Ed. John Carroll. Cambridge, Mass.: MIT Press, 1983.

Whatmore, Sarah. Hybrid Geographies: Natures Cultures Spaces. London: Sage, 2002.

-.'Materialist Returns: Practising Cultural Geography in and for a More-than-Human World'. Cultural Geographies. 13 (2006): 600-09.

Waddington, Conrad H. Chapter 7: 'Stabilization in Complex Systems.' Tools for Thought. Frogmore: Paladin, 1977. 97-116.

Wilson, Elizabeth A. Neural Geographies: Feminism and the Microstructure of Cognition. New York: Routledge, 1998.

-. Psychosomatic: Feminism and the Neurological Body. Durham NC: Duke UP, 2004. 